\title{
Assessing the Level of Sustainability in the Egyptian Banking Sector
}

\author{
Aly Saad Mohamed Dawood and Omar H. Eldahan
}

\begin{abstract}
This research aims to evaluate Egyptian banks' sustainable performance and to rank them according to the assessing framework criteria. The researchers depended on the 2017 annual reports of 26 Egyptian banks and sustainability reports (if available). Then, the banks were categorized according to their type (public, private, or Islamic). Finally, the banks' total assets were extracted in order to further categorize the banks into small and large based on the threshold of EGP 75 billion.

The data from the reports were analyzed using the content analysis application NPV11 to measure the sustainability adoption score. Then, a Kruskal-Wallis test was used to determine if there is a significant difference in sustainability banking performance score of public, private and Islamic sector banks in Egypt. Finally, a Spearman's Rank Correlation was used to test correlation between bank size and sustainability adoption score.

The results showed that there are only two banks that have significantly began to adopt sustainability practices from the private sector while no public or Islamic Bank showed any significant implementation. Furthermore, results reveled that there are nine banks with a score greater than zero and this was reasoned to be a result of the initiatives of the Central Bank of Egypt to provide low-interest loans to support small startup enterprises. Then, it was found that there isn't significant difference in sustainability banking performance score of public, private and Islamic banks in Egypt. Finally, no significant relation between bank size and sustainability adoption score in Egypt was identified.
\end{abstract}

Index Terms-Sustainable Development; Sustainable Banking; Green Banking; SDGs

\section{INTRODUCTION}

Sustainable development (SD) is traditionally defined as the "development that meets the needs of the present without compromising the ability of future generations to meet their own needs" [1]. Egypt currently maintains a foothold on the way towards inclusive development, thus cultivating a path of prosperity through, economic and social justice, and reviving the role of Egypt in regional leadership. According to Egyptian Cabinet of Ministers Egypt Vision 2030 Report [2], the sustainable development goals (SDGs) thus represent a roadmap for maximizing Egypt's competitive advantages to achieve the dreams and aspirations of Egyptians for a dignified and decent life. This report also confirmed that this strategy has followed the sustainable development principles as a general framework for improving the quality of life and welfare of the Egyptian people, taking into consideration the rights of new generations in a prosperous life; thus, dealing with three main dimensions; economic, social, and environmental dimensions.

It is with this concept in mind that sustainable banking becomes an essential mechanism needed to fulfill the sustainable development goals. Realizing the role of finance institutions in achieving sustainable development is essential for pushing such an agenda. The fact that banks do not all operate in the same way and do not follow the same business model can be best understood by placing financial institutions within a more general context.

Although many authors and researchers have development various definitions for sustainable banking, most of them admit that the main aim of banking activities is to create value for shareholders and to satisfy customer needs. Accordingly, it is supposed in this research that sustainable banking is the provision of a wide variety of financial services for individuals and institutions that practice all types of businesses and operations supporting and aligning with the sustainable development pillars (Economic, Social, and Ecological) under the control of shareholders that target the same purposes.

It is assumed that the Egyptian banking industry is still at a very early stage in addressing the SDGs, but they are on the track due orientation of the Central Bank of Egypt towards financial inclusion, microfinance, and socially responsible investments which target many items of the SDGs such as SDG1: No Poverty, SDG2: Zero Hunger, SDG4: Quality Education, SDG7: Affordable and Clean Energy, SDG8: Decent Work and Economic Growth, SDG10: Reduced Inequalities, and SDG11: Sustainable Cities and Communities by providing financial services covering such goals. Some of the targets for these SDGs include reducing the percentage of Egyptians below the extreme poverty line from $4.4 \%$ to $0 \%$ (SDG1), reducing the contribution of the energy sector to total greenhouse gas emissions by $10 \%$ (SDG7), reducing unemployment to $5 \%$ (SDG8), reducing the income and consumption distribution index from 31 to 10 (SDG10), and many other goals and metrics by the year 2030 [2].

The rest of the paper will be organized as follows. Section two will be a review of the literature, section three will contain the data collection and methodology, section four will contain the results of the analysis, and section five will provide the conclusion. (e-mail: ali.saad@hu.edu.eg)

O. H. Eldahan, Faculty of Business \& Economics, Heliopolis University, Egypt.

(e-mail: omar.eldahan@hu.edu.eg) 


\section{LITERATURE REVIEW}

\section{A. On sustainable development}

As was mentioned above, the traditionally used definition has been the one placed by the WCED (1987). However, this one definition can never encompass the full scope of ideas, theories and concepts behind sustainable development. In fact, while the original ideas and motivations behind the ideas of sustainable development originated as a result of the industrialization and subsequent destruction of the natural environment and ecology and a post-World War II world [3], the concept has continued to evolve to encompass many different ideas and paradigms covering issues relation to society, ecology, economy, culture, education, governance, ethics and many other issues and topics. In addition to this, many different aspects lend themselves to the idea of sustainable development including economic and political levels as well as organization and individual levels thus becoming what Pesqueux (2009) dubbed "a vague theory".

For the purpose of this study, the definition for sustainable development will be a relatively broad aspect encompassing all of the ideas, elements, and pillars of sustainability as outlined in the Cabinet of Ministers Egypt Vision 2030 Report and its Sustainable Development Strategy (SDS) [2] which mentions that:

"SDS is based upon the principles of inclusive sustainable development' and 'balanced regional development'; emphasizing the full participation in development, and ensuring its yields to all parties. The strategy, as well, considers equal opportunities for all, closing development gaps, and efficient use of resources to ensure the rights of future generations." [2]

The reason behind using this particular definition is due to the fact that all of the banks are Egyptian and are subject to the regulations of the Central Bank of Egypt which follows the Egyptian SDS. As such, to have a consistent measure of sustainability which can be generalized and applied on all Egyptian banks, this definition was found to be most relevant.

\section{B. Relationship between sustainability and CSR practices on financial performance}

In recent years, the relationship between sustainability and Corporate Social Responsibility (CSR) practices on financial performance has gained increased scrutiny and has been studied from multiple different perspectives [4]-[10]. However, the literature has shown conflicting evidence on the impact of these practices on financial performance and shareholder value. For example, Simpson \& Kohers (2002) investigated the relationship between social and financial corporate performance. The empirical analysis in this study solidly supports the hypothesis that the link between social and financial performance is positive. Similarly, Relaño (2011) demonstrated that there were options for a firm (or a bank) other than just following the mainstream logic of maximizing financial profits; this is the case of the so-called "social banks" which began appearing in the mid-1980s. These results are also supported by Wu \& Shen (2013) who investigated the association between corporate social responsibility and financial performance. The empirical results showed that CSR positively associates with financial performance in terms of return on assets, return on equity, net interest income, and non-interest income. In contrast, CSR negatively associates with non-performing loans. Hence, strategic choice is the primary motive of banks to engage in CSR.

Furthermore, Weber (2017) analyzed the connection between the sustainability performance of Chinese banks and their financial indicators to explore whether sustainability regulations can be implemented without decreasing the financial performance of the banking sector. The study revealed that the environmental and social performance of Chinese banks increased significantly between 2009 and 2013. Furthermore, a bi-directional causality between financial performance and sustainability performance of Chinese banks was found. Based on institutional theory, this interaction may be influenced by the Chinese Green Credit Policy.

However, other studies have found weak, non-existent, or even negative relationships between sustainability and CSR practices with respect to financial performance due to the additional costs associated with more sustainable practices [10]. For example, de Waal \& Frijns (2011) evaluated whether paying dedicated attention to the factors determining the sustainable success of a high-performance organization (HPO) in Asia would result in a sustainable increase in organizational performance. Although Nabil Bank's financial performance had improved, the increase in HPO results was not found to be as much as expected. Possible explanations for this are that there is a perception gap between management and employees with regard to the improvements achieved, and the fact that Nabil Bank has continued with implementing improvement actions that were under way, while not starting additional ones specifically targeted at improving the HPO factors. Also, Shakil et al. (2019) explored different elements of sustainability including the environment, societal, and governance aspects and their impact on banks' financial performance in emerging markets. While the study found a positive association between environmental and social performance with financial performance, it was also found that governance performance had no significant influence on financial performance. Similar results were also found by Aras, Tezcan, Furtuna, \& Kazak (2017) who measured Garanti Bank's corporate sustainability performance along with the main indicators of economic, social, and environmental factors, taking into consideration of the governance indicators. The results depicted that the sustainability performance of Garanti Bank tends to increase during the measured time span. Among all of the sustainability dimensions, the economic dimension was found to have the highest impact on overall sustainability performance. On the other hand, the governance dimension had the lowest impact on overall performance.

\section{Motivations and drivers for implementing sustainability and CSR practices in financial institutions}

Shamshad, Sarim, Akhtar, \& Tabash (2018) tried to identify the critical success factors for sustainable growth of the Indian banking sector and develop a model for Indian banks by using interpretive structural modeling (ISM). It suggests some of the critical measures of sustainability for 
Indian banks. Legal and environmental compliance was determined as the key factor which was driving the other factors of sustainable banking. It would pose a challenge for business concerns for initiating various sustainable steps that would be a motivational factor for generating business opportunities and sustainable collaboration.

Tan, Chew, \& Hamid (2017) aimed to provide a more holistic perspective on rationales that motivate banks to shift towards a sustainable banking operating system by focusing on Maybank. Within the corporation studied, the rationales for moving Maybank toward sustainable banking operating system were driven by macro-, meso- and micro-level drivers. In terms of macro-level drivers, the pressures came from the bank's external environment. In terms of meso-level drivers, stakeholders were viewed as important driving forces for Maybank to integrate sustainability into banking operations. Internal driving forces are likely to emanate from employees, the board of directors, and shareholders. External driving forces result from pressure from customers, governments, competitors, non-governmental organizations (NGOs), and society at large. Micro-level drivers are drivers of sustainable banking that include pressures generated from within the bank's internal environment. Maybank is largely motivated by its mission statement and vision statement, which is articulated in their sustainable banking agenda. A similar approach was conducted which aimed to develop an integrative system that evolving towards sustainability by applying on Brazil. The results indicated that Brazil cannot apply self-organizing system to evolve towards sustainability [14].

In addition, San-Jose, Retolaza, \& Gutierrez-Goiria (2011) studied the differences between traditional financial intermediaries (commercial banks, savings banks and cooperative banks) and ethical banks based on property rights, in which the owner decides the ideology, principles, standards and objectives of the organization. In ethical banking, affinity centers on positive social and ethical values. It was found that transparency of information and placement of assets was factors that differentiate ethical banks from other financial intermediaries. Besides this, [16] analyzed different types of banking approach, each reflecting a distinct business model: banks whose ethical/social approach is mainly based on what they say (e.g. traditional banks), banks whose ethical/social approach is based on what they are (e.g. co-operative banks), and banks whose ethical/social approach is based on what they do (e.g. ethical banks). It was concluded that more ethical behavior leads to both economic performance and social gains which increase wealth for all partners.

Rizzi, Pellegrini, \& Battaglia (2018) contributed towards filling the gap between the new landscape of social financial institutions (SFIs) that is evolving rapidly in Europe and the academic literature on the structures of legitimation that characterize the development of social finance which has been limited. The analysis highlighted that two forms of SFIs (i.e. social impact investment and ethical banking) guide the institutionalization and paradigm building process.

Weber (2017) also concluded that governmental policies, laws, and regulations can have a significant impact on banks' adoption and implementation towards sustainable development and CSR. It was suggested that different strategies can be used to this effect including using "coercive, normative and mimetic mechanisms". As such, it was considered that these results have implications which can (and it some case already are) be applied in Egypt. In the Egyptian situation, through the Egyptian SDS, there is a significant, strategic focus towards sustainable development that is beginning to be seen on the level of different banks. The Central Bank of Egypt is currently supporting various initiatives regarding financial inclusion, social banking, and providing micro-credits in Egypt. However, it should also be noted that since there certain barriers towards the implementation of sustainability practices for smaller banks with fewer resources [9]. As such, there should be careful consideration by the Central Bank of Egypt towards the implementation of an guidelines for sustainability that considers the differences in resources and abilities of the difference sized banks.

Weber (2018) also clarified the important role of banking industry through demonstrating the World Bank estimation of accomplishing SDGs. It showed that from 50 to $80 \%$ of the funds should be covered by governments with the rest coming from the private sector. needed funds that should be provided by governments ranging between 50 to 80 percent and the rest from private sector with significant funding required from financial institutions to reach this goal. It was also mentioned that the estimated funds needed is about $\$ 5$ to $\$ 7$ trillion annual until 2030 achieve the SDGs and it was recommended that banking industry should align their policies toward sustainable finance and investment by providing innovative financial products and this needs that governments should modify their financial regulations.

Additionally, Yip \& Bocken (2018) explored the receptiveness of customers towards sustainable business models pursued by banks. They developed eight sustainable business model archetypes for banking and validated them. It was revealed that "Substitute with digital processes", "adopt a stewardship role", and "encourage sufficiency" were most welcomed by customers. Some archetypes seem at direct odds with current business practice, such as "encourage sufficiency",

\section{Sustainability and CSR reporting in financial institutions}

There are various methods and sources that can be used to gain a measure on the implementation of different sustainability and CSR initiatives of financial institutions. The most relevant source, however, is typically the sustainability and CSR report. The literature has explored the different methods of reporting on these initiatives as well as their overall impact both on sustainability in general, and on the banks and their performance in specific. One approach towards studying this issue was by Darus et al. (2015) in which the study examined the role of internal and external pressures in encouraging CSR reporting among financial institutions in Malaysia. Their findings revealed that the quality of CSR information disclosed improved over the fouryear period. This was considered to be a positive development suggesting that the financial institutions are becoming more socially responsible. The results of the study also revealed that it is the external pressure in the form of concentrated ownership and customers' pressure can either 
inhibit or motivate the quality of CSR reporting while the internal pressure prove not to be a significant driver in promoting the quality of CSR reporting [8].

Moreover, Khan, Islam, Fatima, \& Ahmed (2011) aimed to examine the tendencies of sustainability reporting by major commercial banks in Bangladesh in comparison with global sustainability reporting indicators outlined in the Global Report Initiative (GRI) framework together with banks' predilection toward reporting 16 GRI financial service sector (FSS) specific performance indicators. The results showed that information on society is addressed most extensively with regard to extent of reporting. This is followed by the disclosures prepared on decent works and labor practices and environmental issues. Furthermore, the disclosures of product responsibility information and the information for human rights are rather scarce in banks' reporting; on the subject of FSS-specific disclosures, only 7 items out of the 16 were disclosed by all sample banks.

Kumar \& Prakash (2018) examined the sustainability reporting (SR) practices of the top 10 Indian banks, on parameters derived from a GRI-G4-based persuasive communication framework. The study had three key findings. First, most of the top 10 Indian banks had yet to adopt adequate disclosure and transparency practices in SR. Second, even though environmental and social goals are broadly reported, there are glaring omissions on metrics like "equal remuneration", "occupational health and safety", and "customer privacy." Third, stakeholder engagement focus was weak as reflected in low persuasive appeal of SR content of most banks. Furthermore,

\section{E. Islamic Banking and Sustainability}

And, [22] investigated the role of Islamic banking's positive contribution to the sustainable socioeconomic development. Hence, the integration of the external factors such as governments' economic targets (macro) into Islamic banking's objectives (micro) is needed. The research clearly found that the existing Islamic banking's business and directions did not have a correlated connection with Indonesia's economic objectives. Furthermore, Aliyu, Hassan, Mohd Yusof, \& Naiimi (2017) proposed the use of Islamic moral transaction mode as a moderator in sustainable IMFBs (Islamic microfinance banks) business model. The authors found that Islamic moral transaction mode can moderate the sustainable Islamic banking businesses which can influence the sustenance of IMFBs and the well-being of the society through financial outreach.

Furthermore, Aracil (2019) compared the sustainability practices of Islamic and conventional banks, with the aim of evaluating whether their Corporate Social Responsibility (CSR) strategies converge or diverge in response to formal and informal institutions in an emerging country. The study found that within the same institutional environment, Islamic banks exhibit an implicit commitment to CSR that is mostly based on informal institutions, whereas conventional banks use explicit CSR strategies as a means to fill the voids in formal institutions. In addition, philanthropy-oriented CSR prevails in Islamic banks, as opposed to the CSR actions associated with core business that are followed by conventional banks.
It is also important to note that there is a debate regarding whether the implementation of Murabha, Mudarba, and Mushraka (among other Islamic banking tools) represent a true difference from conventional banking and interest on loans and credit [25]. However, it is generally agreed that all Islamic banks avoid investing and financing certain activities which are considered to be prohibited (Haram) as well as considered to be unethical. These industries which it typically avoids are as follows: alcohol, narcotics, gambling, and other such industries. As such, Islamic portfolios are typically devoid of such activities, and as such are usually considered to be closer to the concept of a social or a sustainable bank in its choices of investments and financing priorities.

Most of the previous studies were concentrating on corporate social responsibility, transferring ethical behavior towards its operation, differentiation between traditional and sustainable financial intermediaries, correlation between financial and sustainable performance, external and internal influence on sustainable development, and finally assessing the priorities of sustainable elements. While this research assessing the extent of applying sustainable development in Egyptian banks utilizing the framework developed by [21] for Indian Banks and also, addressing the orientation of Egyptian banks towards sustainable development according to the Egyptian vision 2030. So, the objective of this research is to evaluate Egyptian banks sustainable performance and to rank them according to the assessing framework criteria. In doing so, the following questions are addressed:

- To what extent do Egyptian banks align with sustainable banking?

- Is there a significant difference between public, private and Islamic in aligning with sustainable banking?

- Is there a relation between bank size (Total Assets) and bank alignment with sustainable banks?

\section{Data collection AND Methodology}

The number of banks in Egypt was 38 banks and the study consist of (26) banks which were available in the form of annual report in English to the researcher in Egypt representing $(26 / 38=68.4 \%)$ of the population of all banks, so it is considered as a full survey. The annual reports and sustainable development report if available on banks website for the year of 2017 were investigated using the content analysis technique. This analysis was conducted to assess and measure the sustainable banking performance of the banks by utilizing NPV11.

To evaluate the sustainable banking performance of the bank, the researcher followed [21] 40 indicators which were categorized into five broad groups with specific indicators representing specific adoption tools in conjunction with the broad outlines of the groups:

- Group 1 Sustainable products and services: represents the financing and lending activities of banks incorporating social and environmental concerns and its weight is $40 \%$ 
TABLE 1: GROUPS OF SUSTAINABLE ADOPTIONS

\begin{tabular}{|c|c|c|c|c|}
\hline $\begin{array}{l}\text { Group 1: Sustainable } \\
\text { Products and Services }\end{array}$ & $\begin{array}{l}\text { Group 2: Environmental } \\
\text { Management Dimension } \\
\text { Indicators }\end{array}$ & $\begin{array}{c}\text { Group 3: Social } \\
\text { Development Dimension } \\
\text { Indicators }\end{array}$ & $\begin{array}{c}\text { Group 4: Internal Socio- } \\
\text { Ethical Conduct }\end{array}$ & $\begin{array}{c}\text { Group 5: Sustainability } \\
\text { Code of Conduct, } \\
\text { Reporting, \& ESG } \\
\text { Indexing }\end{array}$ \\
\hline Sustainable financing & $\begin{array}{c}\text { Certified environmental } \\
\text { management system (ISO } \\
14001 \text { ) }\end{array}$ & $\begin{array}{l}\text { Community involvement } \\
\text { program }\end{array}$ & $\begin{array}{c}\text { Policy and procedure } \\
\text { concerning anti-corruption }\end{array}$ & $\begin{array}{l}\text { Business responsibility } \\
\text { report disclosure }\end{array}$ \\
\hline Climate fund & Sector specific exclusion & Charity and sponsoring & $\begin{array}{l}\text { Policy and procedure } \\
\text { concerning human rights }\end{array}$ & Environment policy \\
\hline Environmental loan & $\begin{array}{c}\text { Environmental risk } \\
\text { management in lending } \\
\text { policy }\end{array}$ & $\begin{array}{l}\text { Financial literacy and } \\
\text { financial counseling }\end{array}$ & $\begin{array}{l}\text { Policy on business } \\
\text { ethics/values }\end{array}$ & GRI membership \\
\hline Micro-finance & $\begin{array}{l}\text { Quantitative target about } \\
\text { environment care } \\
\text { initiatives }\end{array}$ & $\begin{array}{l}\text { Training and skills } \\
\text { development }\end{array}$ & Policy on labor practices & $\begin{array}{c}\text { Signatory to Equator } \\
\text { Principles }\end{array}$ \\
\hline $\begin{array}{c}\text { Sustainable advocacy } \\
\text { services }\end{array}$ & $\begin{array}{c}\text { Adoption of } \\
\text { environmentally friendly } \\
\text { technologies }\end{array}$ & Community consultations & $\begin{array}{l}\text { Gender equity and } \\
\text { diversity }\end{array}$ & $\begin{array}{l}\text { Adherence to UN Global } \\
\text { Compact principles }\end{array}$ \\
\hline Green mortgage & & $\begin{array}{l}\text { Targets for community } \\
\text { investment }\end{array}$ & & Signatory to UNEP FI \\
\hline $\begin{array}{c}\text { Socially responsible } \\
\text { investment }\end{array}$ & & ISO26000 certification & & $\begin{array}{l}\text { Adherence to NVGs } \\
\text { disclosure (country } \\
\text { specific guidelines) }\end{array}$ \\
\hline $\begin{array}{l}\text { Financial inclusion } \\
\text { product }\end{array}$ & & $\begin{array}{l}\text { Healthcare and sanitation } \\
\text { program }\end{array}$ & & BSE GREENEX Indexing \\
\hline $\begin{array}{c}\text { Venture capital for } \\
\text { environmental saving } \\
\text { product }\end{array}$ & & $\begin{array}{l}\text { Access points for financial } \\
\text { services in low populated } \\
\text { or remote areas }\end{array}$ & & \\
\hline Green bonds & & & & \\
\hline
\end{tabular}

- Group 2 Environment management dimension indicators: reflects the commitment of banks towards environmentally responsible behavior through the initiatives taken by the banks to adopt environmental management system and its weight is $20 \%$.

- Group 3 Social development dimension indicators: reflects the socially responsible behavior of banks and how banks' actually creating a social development in the society and its weight is $20 \%$.

- Group 4 Internal socio-ethical conducts: reflects banks commitment towards maintaining high socioethical standards in the banks through policies towards anticorruption, human right and business ethics, etc. and its weight is $10 \%$.

- Group 5 sustainability code of conduct, reporting, ESG indexing: reflects the bank to what extent the bank is committed to global sustainability code of conduct and engaging with all its stakeholders in disclosing the nonfinancial performance of the bank and its weight is $10 \%$.

TABLE 2: StAGE SCORE LEVEL OF ADOPTION OF SUSTAINABLE BANKING

\begin{tabular}{|c|c|c|c|}
\hline First Stage & Second Stage & Third Stage & Fourth Stage \\
\hline $0-5$ & $6-10$ & $11-15$ & $16-20$ \\
\hline $\begin{array}{c}\text { Insignificant } \\
\text { adoption }\end{array}$ & Begin to adopt & $\begin{array}{c}\text { Satisfactory } \\
\text { adoption }\end{array}$ & $\begin{array}{c}\text { Substantial } \\
\text { adoption }\end{array}$ \\
\hline
\end{tabular}

In order to measure the sustainability adoption of banks, a mixed-research method was applied. This mixed research method first used qualitative data from the annual reports and sustainability reports (if available) from all of the sampled banks. These reports were then analyzed, and the content was quantified into numerical codes based on their relationship to sustainable development and the various pillars of sustainability. This is based on key phrases in the text. Based on the number of times these phrases were mention in the annual or sustainability reports, the banks received a score measuring their overall sustainability adoption.

Then based on the results of the study, tests of correlation and comparisons of means were conducted in order to determine the significance of the sustainability adoption among the various banks.

The following steps were taken to answer the research questions:

(1) A Content analysis technique was used to count the phrases of five different categories as in table 1 and table 2 . Then sum the multiplication for each group counting results by its weights.

(2) Refer to previous results in a, the banks sustainable adoption was ranked to find out which banks groups public, private, and Islamic are more align towards sustainable banks according to table 3 .

(3) Utilizing Kruskal-Wallis test to measure significant difference between private, public, and Islamic banks sustainable performance table 4 .

(4) Applying correlation to measure the relation between the banks sizes and the sustainable adoption for each individual group and with the weighted average (sustainable adoption) results table 5 considering big size whose total assets value exceed EGP 75 billion and the rest are the small size banks. 


\section{RESULTS}

The results of the application of NPV11 on 26 Egyptian banks in figure 1 and Table 3 showed sustainable banking performance score, where only two banks produced sustainability reports (Bank of Alexandria and Arab African international bank) and they were the only banks to reach the 1st level beginning to adopt significant coverage of the SDGs. Meanwhile the rest of the sample had non-significant adoption, even though some banks' sustainability score was non-zero. This reflect that the Central Bank of Egypt start to take serious steps to push banking industry in Egypt toward sustainable banking which isn't aligned with Egyptian vision 2030 .

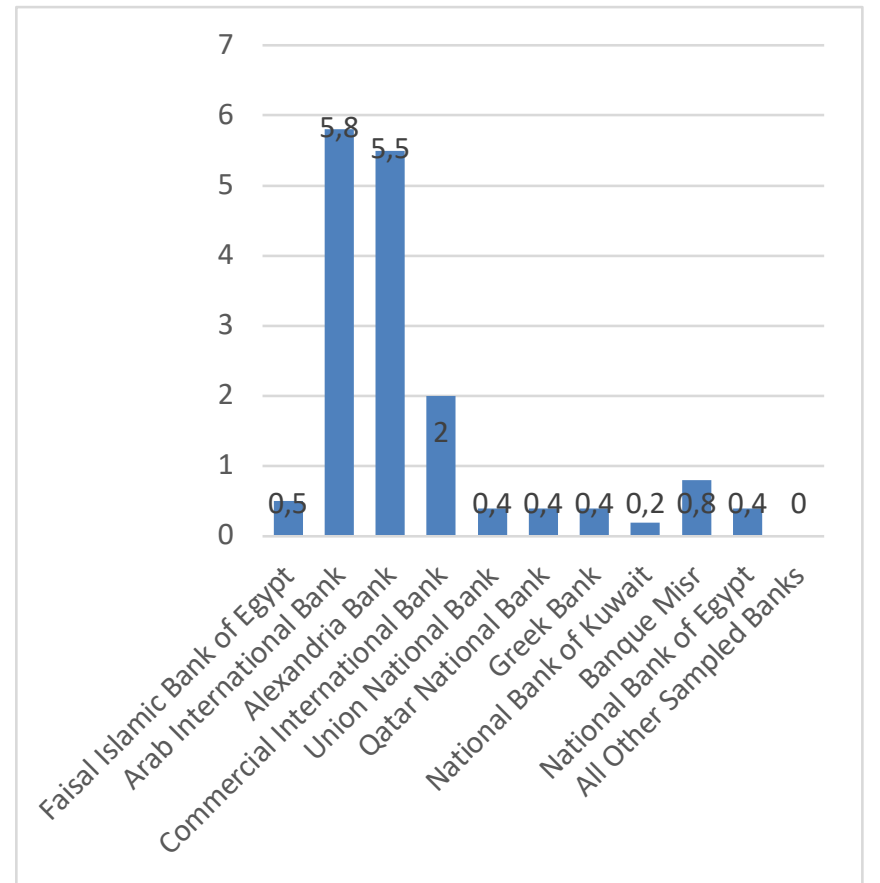

Fig. 1. Sustainable Banking Performance Score in Egypt

Figure 2 and table 3 also showed that public banks address unsustainable adoption by their low level score, but it exceed zero score because may start to apply initiatives of the central bank of Egypt that decline loan interest to 5 and $7 \%$ for small startup enterprises dated 5 of March 2017 [26].

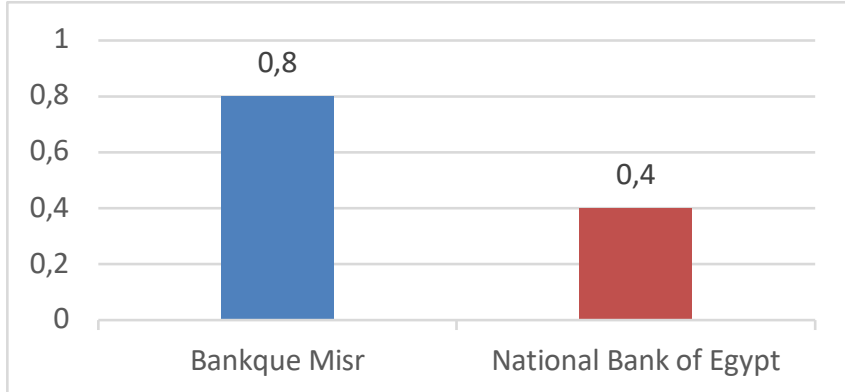

Fig. 2. Sustainable Banking Performance Score of Public Banks in Egypt

Figure 3 and table 3 showed that only two are in the beginning of adoption while the rest are non-significant. But Commercial International Bank is the only non-significant on the way toward sustainability with a score of 2 , while the rest is less than 1 or zero.

Figure 4 and Table 3 showed that all Islamic banks in Egypt had non-significant adoption. But both Abu Dhabi Islamic Bank and Faisal Islamic Bank showed that they are on the way towards sustainability by 0.8 and 0.5 respectively due to their increasing trends towards microfinance according to content analysis results. While El-Baraka bank didn't show any trends toward sustainability with a score of zero.

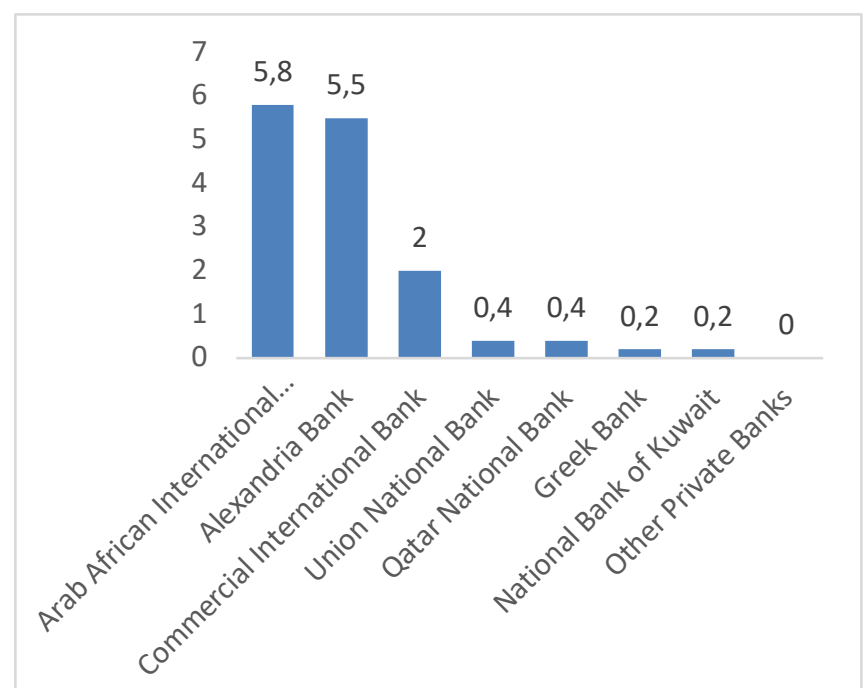

Fig. 3. Sustainable Banking Performance Score of Private Banks in Egypt

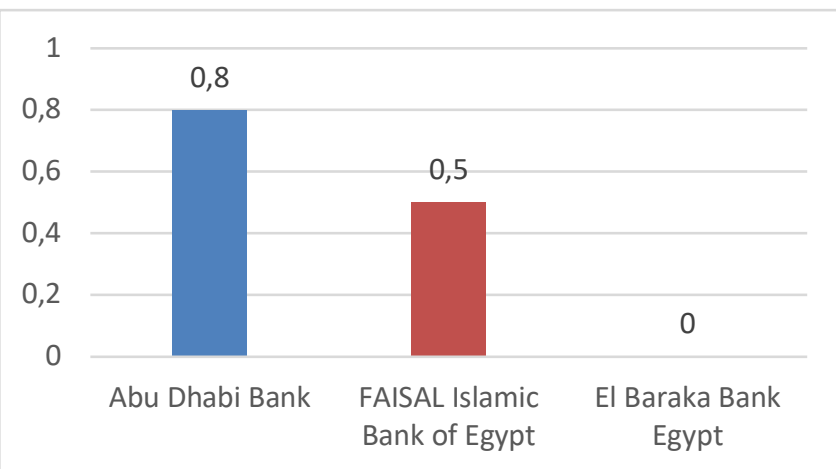

Figure 4: Sustainable Banking Performance Score of Islamic in Egypt 
TABLE 3: BANKS SIZE AND LEVEL OF ADOPTION

\begin{tabular}{|c|c|c|c|c|}
\hline Bank Name & Bank Total Assets & Score & Rank & Level of adaption \\
\hline $\begin{array}{c}\text { Arab African International } \\
\text { Bank }\end{array}$ & $211,561,929$ & 5.8 & 1 & Beginning to adopt \\
\hline Alexandria Bank & $77,697,000$ & 5.5 & 2 & Beginning to adopt \\
\hline Commercial International Bank & $294,771,321$ & 2 & 3 & Insignificant adoption \\
\hline Bankque Misr & $786,943,607$ & 0.8 & 4 & Insignificant adoption \\
\hline Abu Dhabi Bank & $3,144,150,817$ & 0.8 & 5 & Insignificant adoption \\
\hline Faisal Islamic Bank of Egypt & $85,025,627$ & 0.5 & 6 & Insignificant adoption \\
\hline Union National Bank & $28,694,160$ & 0.4 & 7 & Insignificant adoption \\
\hline Qatar National Bank & $219,606,059$ & 0.4 & 8 & Insignificant adoption \\
\hline National Bank of Egypt & $1,464,296,255$ & 0.4 & 9 & Insignificant adoption \\
\hline Greek Bank & $64,768,000$ & 0.2 & 10 & Insignificant adoption \\
\hline National Bank of Kuwait & $1,549,058,760$ & 0.2 & 11 & Insignificant adoption \\
\hline Arab Bank Corporation - Egypt & $8,437,838$ & 0 & 12 & Insignificant adoption \\
\hline Arab Investment Bank & $23,853,718$ & 0 & 13 & Insignificant adoption \\
\hline National Bank of Greece & $31,901,400$ & 0 & 14 & Insignificant adoption \\
\hline Canal El-Suez Bank & $39,956,351$ & 0 & 15 & Insignificant adoption \\
\hline CREDIT AGRICOLE - EGYPT & $45,517,084$ & 0 & 16 & Insignificant adoption \\
\hline Ahli United Bank & $46,988,647$ & 0 & 17 & Insignificant adoption \\
\hline $\begin{array}{c}\text { Export Development Bank of } \\
\text { Egypt }\end{array}$ & $48,229,020$ & 0 & 18 & Insignificant adoption \\
\hline El Baraka Bank Egypt & $50,278,975$ & 0 & 19 & Insignificant adoption \\
\hline $\begin{array}{c}\text { Housing and Development } \\
\text { Bank }\end{array}$ & $51,939,002$ & 0 & 20 & Insignificant adoption \\
\hline Bank Audi & $55,971,016$ & 0 & 21 & Insignificant adoption \\
\hline $\begin{array}{c}\text { Societe Arabe Internaitonale de } \\
\text { Banque (SAIB) }\end{array}$ & $80,703,949$ & 0 & 22 & Insignificant adoption \\
\hline Arab International Bank & $84,670,671$ & 0 & 23 & Insignificant adoption \\
\hline HSBC Bank Egypt S.A.E. & $88,697,015$ & 0 & 24 & Insignificant adoption \\
\hline Mashrek Bank & $125,188,236$ & 0 & 25 & Insignificant adoption \\
\hline ATTIJARIWAFA Bank & $562,093,386$ & 0 & 26 & Insignificant adoption \\
\hline
\end{tabular}


The Kruskal-Wallis test Table 4 which was utilized to determine if there is a significant difference in sustainability banking performance score of public, private and Islamic sector banks in Egypt. The results of Kruskal-Wallis test revealed that there is no significant difference in the sustainable banking performance score of public banks (mean $=0.60)$, private sector banks (mean $=0.69$ ), and Islamic banks $($ mean $=0.43)($ Chi-Square $(2,26)=3.739, \mathrm{p}=0.154)$ which is contradicted with most researchers that investigated the contribution of Islamic banks in the well-being of societies by utilizing microfinance in Indonesia and Bangladesh. This result also confirmed once again that the Central Bank of Egypt should take further serious steps toward pushing banks sector in Egypt to sustainable banking. TABLE 4: RESULTS OF KRUSKAL-WALLIS TEST

\begin{tabular}{cccc}
\hline \hline & Chi-Square & df & Asymp Sig. \\
\hline Score & 3.739 & 2 & 0.154 \\
\hline \hline
\end{tabular}

The Spearman's Rank Correlation test was then used in Table 5 to measure the correlation between bank size and sustainable adoption. From this the results showed that there were significant and positive relationships which contradicted the previous results shown in table 1. It was then determined that the reason for this was due to the number of banks received a score of 0 in the results which skewed the results. Thus, the process was repeated after excluding banks with scores of zeros and the results then showed nonsignificant correlation in Egypt which was more consistent with the earlier results.

TABLE 5: SPEARMAN's CORRELATION OF SUSTAINABILITY SCORE AND BANK SIZE

\begin{tabular}{cccc}
\hline \hline & $\begin{array}{c}\text { Correlation } \\
\text { Coefficient }\end{array}$ & $\begin{array}{c}\text { Sample } \\
\text { Size }\end{array}$ & P-Value \\
\hline Large Banks & 0.55 & 26 & 0.00 \\
Small Banks & -0.13 & 11 & 0.71 \\
\hline \hline
\end{tabular}

\section{CONCLUSIONS}

In this paper we tried to measure bank sustainability performance in Egypt by following [21] through 40 indicators. The results showed that there are only two banks significantly beginning to adopt from the private sector while there are no banks that adopted from either public or Islamic banks.

As it could be seen from the statistical analysis, only two banks in Egypt showed any significant level of focus the efforts on adopting sustainability practices as shown in their annual and sustainability reports. This shows that even though there is a weak level of preparation in Egypt for the implementation of sustainability practices in the Egyptian banking sector, Egypt has at least started to be on track as it prepares to implement the Egyptian Sustainable Development Vision 2030 which is highly dependent on the banking sector for sustainability practices such as financial inclusion and the low-interest loans for MSMEs. Furthermore, the analysis also demonstrates the surprising result that Islamic banks were not more likely to have implemented sustainability practices in their operations, despite such concepts being central to the idea of an Islamic Bank. This raises the issue of how much the Islamic Banks actually implement and contribute to the sustainability initiatives of Egypt in this context. However, it should also be noted that various banks demonstrated non-zero levels of implementation of sustainability concepts, which shows the results and impact of the efforts of the Central Bank of Egypt in encouraging various sustainability practices in their operations (such as the decision to provide loans at 5\% and $7 \%$ to MSMEs) which has the potential to alleviate poverty and income inequality.

What the analysis ultimately shows is the status of adoption which in Egypt is still at its earliest stages; however, there has been some progress in this regard. While the banking sector still has only a very preliminary implementation of sustainability practices, this situation is improving as shown by the two banks that already have sustainability reporting as part of their overall annual reports. Future research may look at the issue in order to determine the overall impact of the implementation of sustainability by these banks, and whether the banks managed to improve their operations and financial results compared with the banks that had no implementation of sustainability practices in their operations and reports.

\section{REFERENCES}

[1] WCED, "Report of the World Commission on Environment and Development: Our Common Future," 1987.

[2] ECOM, "Egypt Vision 2030." Egyptian Cabinet of Ministers, 2017.

[3] Y. Pesqueux, "Sustainable development: a vague and ambiguous "theory,", Soc. Bus. Rev., vol. 4, no. 3, pp. 231-245, 2009.

[4] W. G. Simpson and T. Kohers, "The link between corporate social and financial performance: Evidence from the banking industry," J. Bus. Ethics, 2002

[5] F. Relaño, "Maximizing social return in the banking sector," Corp. Gov., 2011.

[6] A. de Waal and M. Frijns, "Longitudinal research into factors of high performance: The follow-up case of Nabil Bank," Meas. Bus. Excell., 2011.

[7] M. W. Wu and C. H. Shen, "Corporate social responsibility in the banking industry: Motives and financial performance," J. Bank. Financ., 2013.

[8] F. Darus, S. Mad, and M. Nejati, "Ethical and Social Responsibility of Financial Institutions: Influence of Internal and External Pressure," Procedia Econ. Financ., 2015.

[9] O. Weber, "Corporate sustainability and financial performance of Chinese banks," Sustain. Accounting, Manag. Policy J., 2017.

[10] M. H. Shakil, N. Mahmood, M. Tasnia, and Z. H. Munim, "Do environmental, social and governance performance affect the financial performance of banks? A cross-country study of emerging market banks," Manag. Environ. Qual. An Int. J., vol. 30, no. 6, pp. 1331-1344, 2019.

[11] G. Aras, N. Tezcan, O. K. Furtuna, and E. H. Kazak, "Corporate sustainability measurement based on entropy weight and TOPSIS: A Turkish banking case study," Meditari Account. Res., 2017.

[12] M. Shamshad, M. Sarim, A. Akhtar, and M. I. Tabash, "Identifying critical success factors for sustainable growth of Indian banking sector using interpretive structural modeling (ISM)," Int. J. Soc. Econ., 2018.

[13] L. H. Tan, B. C. Chew, and S. R. Hamid, "A holistic perspective on sustainable banking operating system drivers: A case study of Maybank group," Qual. Res. Financ. Mark., 2017.

[14] O. S. Donaires, L. O. Cezarino, A. C. F. Caldana, and L. Liboni, "Sustainable development goals - an analysis of outcomes," Kybernetes, vol. 48, no. 1, pp. 183-207, 2019.

[15] L. San-Jose, J. L. Retolaza, and J. Gutierrez-Goiria, “Are Ethical Banks Different? A Comparative Analysis Using the Radical Affinity Index," J. Bus. Ethics, 2011.

[16] L. Rayman-Bacchus, F. Relano, and E. Paulet, "Corporate responsibility in the banking sector: A proposed typology for the German case," Int. J. Law Manag., 2012.

[17] F. Rizzi, C. Pellegrini, and M. Battaglia, "The structuring of social finance: Emerging approaches for supporting environmentally and socially impactful projects," J. Clean. Prod., 2018.

[18] O. Weber, The Financial Sector and the SDGs: Interconnections 
and Future Directions. Waterloo, Canada: Centre for International Governance Innovation, 2018.

[19] A. W. H. Yip and N. M. P. Bocken, "Sustainable business model archetypes for the banking industry," J. Clean. Prod., 2018.

[20] M. H. U. Z. Khan, M. A. Islam, J. K. Fatima, and K. Ahmed, "Corporate sustainability reporting of major commercial banks in line with GRI: Bangladesh evidence,” Soc. Responsib. J., 2011.

[21] K. Kumar and A. Prakash, "Developing a framework for assessing sustainable banking performance of the Indian banking sector," Soc. Responsib. J., 2018.

[22] A. Pratiwi, "Islamic banking contribution in sustainable socioeconomic development in Indonesia: An epistemological approach," Humanomics, 2016.

[23] S. Aliyu, M. K. Hassan, R. Mohd Yusof, and N. Naiimi, "Islamic Banking Sustainability: A Review of Literature and Directions for Future Research," Emerging Markets Finance and Trade. 2017.

[24] E. Aracil, "Corporate social responsibility of Islamic and conventional banks," Int. J. Emerg. Mark., vol. 14, no. 4, pp. 582 $600,2019$.

[25] F. K. Khan and M. Porzio, Islamic Banking and Finance in the European Union: A Challenge. Cheltenham, 2010.

6] CBE, “Annual Report." Central Bank of Egypt, 2018.

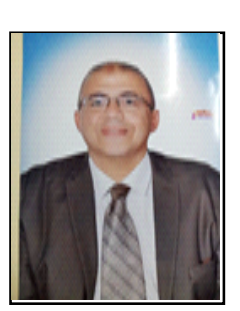

Dr. Aly Saad is an Associate Professor of Business Administration at Sadat Academy for Management Sciences since 2006. He received his BA, MSc, and $\mathrm{PhD}$ degrees in Business Administration at the Faculty of Management, Sadat Academy for Management Sciences.

Dr. Saad is seconded to Heliopolis University for sustainable Development since October 2016 at the Faculty of Business and Economics as an Acting ViceDean for Undergraduate Studies and Student Affairs. Dr. Saad conducted and participated in many training programs for Egyptian and Arab managers from public and private sectors. $\mathrm{He}$ authored various books in Arabic and English in the fields of finance, investment, and banking in addition to a business administration handbook for training purposes. He has participated in dozens of master and PhDs theses defense committees and supervised more than twenty master and PhD theses in the fields of finance and business administration. He has published nine research articles in finance and investment in different national and international scientific journals in the last eight years

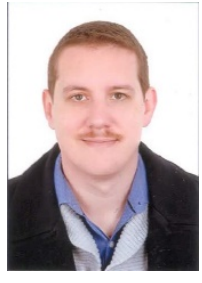

Omar H. Eldahan, M.Sc., M.A. is an Assistant Lecturer of Business Administration at the Faculty of Business \& Economics, Heliopolis University and a Doctoral Candidate at Cairo University. He received his B.Sc. in 2012 from the University of New Brunswick, Canada and the Sadat Academy for Management Sciences as a dual degree. He then received his M.A. in Information \& Communication Technology for Education for Sustainable Development from Frederick University, Cyprus. He also received his M.Sc. in Business Administration from Cairo University, Egypt.

Mr. Eldahan has published 10 manuscripts in various international journals, books, and publications such as the Global Business Review. Mr. Eldahan is mainly focused on research topics in the intersection of Business Studies and Sustainable Development. 